\title{
KAJIAN MACAM BOKASHI DAN VARIETAS TERHADAP PERTUMBUHAN DAN PRODUKSI TANAMAN JAGUNG (Zea mays L.)
}

\section{Study on the Types of Bokashi and Varieties against the Growth and Production of Maize (Zea mays L.)}

\author{
M. Syifa', Ana Amiroh, dan Suharso \\ Fakultas Pertanian Universitas Islam Darul ‘Ulum Lamongan Jawa Timur \\ Korespondensi : muhammad.syifak@gmail.com
}

\begin{abstract}
ABSTRAK
Tanaman jagung (Zea mays L.) adalah salah satu tanaman pangan pokok kedua setelah tanaman padi di Indonesia. Sebagian masyarakat di Indonesia mengkonsumsi jagung sebagai makanan pokok. Mengingat pentingnya komoditas tanaman jagung, sebagai salah satu makanan pokok. Maka perlu adanya upaya untuk meningkatkan pertumbuhan dan produksi tanaman jagung. Salah satu upaya tersebut adalah dengan pengaplikasian bokashi dan varietas. Penelitian ini dilaksanakan di Desa Kranji, Kecamatan Paciran, Kabupaten Lamongan. Dengan ketinggian tempat \pm 5 meter dpl. Waktu penelitian dilaksanakan pada bulan Maret sampai bulan Juni 2019. Penelitian ini menggunakan Rancangan Acak Kelompok (RAK) Faktorial, yang terdiri dari dua faktor yaitu : bokashi dan varietas. Setiap faktor terdiri dari 3 level yang diulang 3 kali ulangan yaitu : faktor pertama, bokashi terdiri dari 3 level yaitu tanpa bokashi, bokashi kandang sapi, bokashi kandang ayam. Faktor kedua, varietas terdiri dari 3 level yaitu BISI 18, NK7328 SUMO, dan BISI 2. Pengamatan pertumbuhan dan produksi tanaman jagung meliputi fase vegetatif (tinggi tanaman dan jumlah daun) dan fase generatif (panjang tongkol, diameter tongkol, berat tongkol tongkol kupasan lepas panen, berat tongkol kupasan lepas panen per hektar dan berat 1000 biji). Hasil penelitian menunjukkan interaksi antara perlakuan bokashi dan varietas terhadap tinggi tanaman jagung dan perlakuan varietas NK7328 SUMO berpengaruh baik pada semua parameter pengamatan.
\end{abstract}

Kata Kunci : Bokashi, Varietas, Jagung.

\section{ABSTRACT}

Corn plants (Zea mays L.) are one of the second staple food plants after rice plants in Indonesia. Some people in Indonesia consume corn as a staple food. Given the importance of corn crop commodities, as one of the staple foods. So there needs to be an effort to increase the growth and production of corn plants. One such effort is the application of bokashi and varieties. This research was conducted in Kranji Village, Paciran District, Lamongan Regency. With the altitude of \pm 5 meters above sea level. The time of the study was conducted from March to June 2019. This study uses Factorial Randomized Block Design (RBD), which consists of two factors, namely: bokashi and varieties. Each factor consists of 3 levels that are repeated 3 times, namely: the first factor, bokashi consists of 3 levels, namely without bokashi, bokashi cow cage, bokashi chicken coop. The second factor, the variety consisted of 3 levels namely BISI 18, NK7328 SUMO, and BISI 2. Observation of growth and production of maize plants includes vegetative phase (plant height and number of leaves) and generative phase (ear length, ear diameter, weight of peel cob ear off harvest, weight of peel cob off harvest per hectare and weight of 1000 seeds). The results showed the interaction between the treatment 
of bokashi and varieties on the height of maize plants and the treatment of NK7328 SUMO varieties had a good effect on all parameters of observation.

Keywords: Bokashi, Varieties, Corn.

\section{PENDAHULUAN}

Tanaman jagung (Zea mays L.) adalah salah satu tanaman pangan pokok kedua setelah tanaman padi (Oryza sativa L.) di Indonesia. Sebagian masyarakat di Indonesia mengkonsumsi jagung sebagai makanan pokok, seperti di wilayah Madura. Jagung (Zea mays L.) mengandung nilai gizi dalam jumlah yang cukup besar, dibanding dengan tanaman biji-bijian lainnya. Jagung dapat menyuplai asupan kalori $15-56 \%$ total kalori harian (Ratna, 2009).

Mengingat pentingnya komoditas tanaman jagung, sebagai salah satu makanan pokok. Maka perlu adanya upaya untuk meningkatkan pertumbuhan dan produksi tanaman jagung yaitu dengan pemberian pupuk organik. Pupuk organik dapat meningkatkan kesuburan tanah dan kandungan unsur hara dalam tanah. Selain itu penggunaan sumber bahan baku pembuatan pupuk organik juga mampu meningkatkan kualitas pupuk organik dan penambahan inokulum juga mampu untuk meningkatkan unsur hara makro, sehingga kualitas pupuk organik akan menjadi lebih baik (Sutedjo, 2010).

Bokashi merupakan salah satu pupuk organik yang dihasilkan dari fermentasi bahan organik dengan bantuan EM4. EM4 merupakan kultur campuran berbagai jenis mikroorganisme yang bermanfaat yaitu bakteri asam laktat, bakteri fotosintetik, Actinomycetes, Streptomycetes sp., dan ragi. Aplikasi bokashi sangat bermanfaat untuk meningkatkan sifat-sifat tanah, baik fisik, kimia maupun biologis. Sehingga dapat meningkatkan kesuburan tanah serta meningkatkan pertumbuhan dan produksi suatu tanaman (Kusuma, 2013).

Selain pemupukan, penggunaan varietas jagung yang unggul akan meningkatkan pertumbuhan dan produksi tanaman jagung. Pemilihan varietas yang unggul dan sesuai kondisi lingkungan setempat, maka penggunaan benih tanaman jagung yang bermutu tinggi merupakan langkah awal menuju keberhasilan dalam usahatani jagung (Suryana, 2010). Tujuan penelitian ini yaitu untuk mengetahui respon pemberian macam bokashi dan varietas terhadap pertumbuhan dan produksi tanaman jagung (Zea mays L.).

\section{METODOLOGI PENELITIAN}

\section{Tempat dan Waktu}

Penelitian ini dilaksanakan di Desa Kranji, Kecamatan Paciran, Kabupaten Lamongan. Ketinggian tempat \pm 5 meter dpl. Waktu penelitian dilaksanakan pada bulan Maret sampai bulan Juni 2019.

\section{Bahan dan Alat}

Bahan yang digunakan dalam penelitian ini adalah benih tanaman jagung varietas BISI 18, NK7328 SUMO, BISI 2, bokashi kandang Sapi, bokashi kandang ayam, pestisida untuk pengendalian hama dan penyakit dan bahan-bahan penting lainnya. Alat yang digunakan yaitu cangkul, tugal, ajir, alat pengukur, meteran, timbangan, jangka sorong, papan nama, alat tulis dan peralatan penting lainnya.

\section{Metode Penelitian}

Penelitian ini menggunakan Rancangan Acak Kelompok (RAK) Faktorial, yang terdiri dari dua faktor yaitu : bokashi dan varietas. Setiap faktor terdiri dari 3 level yang diulang 3 kali ulangan yaitu : faktor pertama, bokashi terdiri dari 3 level yaitu tanpa bokashi, bokashi kandang sapi, 
bokashi kandang ayam. Faktor kedua, varietas terdiri dari 3 level yaitu BISI 18, NK7328 SUMO, dan BISI 2.

\section{Pelaksanaan Penelitian}

Pembuatan Bokashi Kandang Sapi dan Ayam

Bokashi kandang sapi dan ayam dibuat dengan komposisi sebagai berikut: pupuk kandang sapi atau ayam (150 kg), dedak $(25 \mathrm{~kg})$, sekam padi $(75 \mathrm{~kg})$, EM-4 $(250 \mathrm{ml})$, gula tetes $(100 \mathrm{ml})$, dan air secukupnya. Berikut ini adalah cara pembuatan bokashi kandang sapi dan ayam: 1) Larutkan EM-4 dan gula tetes ke dalam air secukupnya, 2) Pupuk kandang sapi atau ayam, sekam padi dan dedak dicampur secara merata, kemudian digundukan diatas lantai yang kering minimal ketinggian $20 \mathrm{~cm}$, 3) Kemudian siramkan larutan EM-4 dan gula tetes perlahan-lahan ke adonan secara merata, 4) Selanjutnya adonan tersebut ditutup plastik atau karung goni selama 7 hari. Pertahankan suhu adonan maksimal $50^{\circ} \mathrm{C}$, bila suhunya lebih maka turunkan dengan membolak-balik adonan. Pemeriksaan suhu dilakukan setiap hari agar suhunya tetap optimal dan tidak merusak adonan bokashi, 5) Setelah 7 hari, bokashi telah selesai terfermentasi dan siap untuk diaplikasikan ke tanaman.

\section{Pengolahan Lahan}

Pengolahan lahan dilakukan untuk membersihkan gulma dan memperbaiki sifat fisik, kimia dan biologi tanah. Tanah diolah dan digemburkan dengan cara pembajakan atau mencangkul sedalam 15 $\mathrm{cm}$, kemudian dibuat guludan/petakan, lebar $2,5 \mathrm{~m}$ dan panjang $2 \mathrm{~m}$. Jarak antaraguludan/petakan dibuat saluran selebar $50 \mathrm{~cm}$ untuk mengalirkan air, sedangkan jarak antar ulangan $1 \mathrm{~m}$ per petakan dan dibutuhkan 27 petak perlakuan.

\section{Penanaman}

Penanaman dilakukan dengan cara ditugal sedalam $3 \mathrm{~cm}$ dengan jumlah benih 1 biji per lubang dengan jarak lubang dalam baris $20 \mathrm{~cm}$ dan jarak lubang antar baris $70 \mathrm{~cm}$. Sehingga seluruh luas guludan/petakan $5 \mathrm{~m}^{2}$ per petak, jumlah tanaman dalam satu petak terdapat 36 lubang tanaman.

\section{Pemupukan}

Pupuk dasar berupa bokashi kandang sapi dan ayam diberikan sebelum tanam atau saat pengolahan lahan dengan memberikan secara merata pada petakpetak perlakuan. Bokashi kandang sapi dan ayam dengan dosis $20 \mathrm{t} / \mathrm{ha}$, sedangkan penggunaan pupuk urea dengan dosis 300 $\mathrm{kg} / \mathrm{ha}$, pemupukan urea diberikan selama 10 hari sekali sampai fase generatif. Masing-masing petak perlakuan mendapat suplai bokashi kandang sapi dan ayam sebanyak $10 \mathrm{~kg}$ dan pupuk urea sebanyak $0,15 \mathrm{~kg}$.

\section{Penyulaman}

Penyulaman dilakukan pada saat ada benih jagung yang tidak tumbuh, atau tumbuh abnormal dengan benih yang baru. Penyulaman dilakukan pada umur $7 \mathrm{hst}$.

\section{Penyiangan}

Penyiangan dilakukan 3 kali yaitu penyiangan pertama dilakukan saat tanaman berumur $14 \mathrm{hst}$, penyiangan kedua dilakukan saat tanaman berumur 28 hst dan penyiangan ketiga dilakukan saat tanaman berumur 42 hst.

\section{Pengairan}

Tanaman jagung membutuhkan air yang cukup, terutama pada fase vegetatif (pertumbuhan dan perkembangan tanaman jagung) sampai fase generatif (masa pengisian biji dalam tongkol). Pengairan melalui air hujan, jika tidak ada hujan. Maka pengairan dilakukan dengan mengalirkan air melalui parit diantara barisan tanaman jagung.

\section{Pengendalian OPT}

Jika terjadi serangan dan diduga mengakibatkan kerusakan tanaman karena populasi OPT maupun penyakit melampaui ambang batas pengendalian, maka sudah 
dipersiapkan pestisida sebagai pencegahan OPT.

\section{Pemanenan}

Pemanenan jagung pada penelitian ini melakukan pemanenan masak secara fisiologis (masak tua), yang ditandai dengan berangsur-angsurnya batang, daun dan kelobot berwarna kuning. Jagung yang telah masak fisiologis memiliki kadar air $20 \%$. Penanganan pasca panen harus memperhatikan kadar air agar mutunya terjamin terutama dalam usaha mempertahankan kandungan gizi pada biji jagung.

\section{Pengeringan}

Pengeringan yang dilakukan adalah dengan penjemuran tongkol jagung yang bijinya masih melekat dibawah terik matahari dengan cara dihamparkan diatas terpal. Setelah itu dilakukan pemipilan apabila kadar airnya mencapai $8 \%$ untuk menjaga lama penyimpanan.

\section{Pengamatan dan Pengolahan Data}

Pengamatan pertumbuhan dan produksi tanaman jagung meliputi fase vegetatif (tinggi tanaman dan jumlah daun) dan fase generatif (panjang tongkol, diameter tongkol, berat tongkol kupasan lepas panen, berat 1000 biji dan berat tongkol kupasan lepas panen per hektar). Pengamatan fase vegetatif dilakukan saat tanaman berumur $14 \mathrm{hst}$, dengan interval 14 hari sekali. Sedangkan pengamatan fase generatif dilakukan saat panen. Data yang diperoleh dari hasil pengamatan dihitung dengan analisa sidik ragam dan dilanjutkan dengan Uji BNT 5\%.

\section{HASIL PENELITIAN}

\section{Tinggi Tanaman}

Hasil analisa sidik ragam menunjukkan bahwa terjadi interaksi antara perlakuan macam bokashi dan varietas terhadap tinggi tanaman pada pengamatan umur 14 hst, 28 hst, 42 hst, dan 56 hst. Rata-rata tinggi tanaman jagung dapat dilihat pada Tabel 1.

Tabel 1. Rata-rata tinggi tanaman jagung terhadap pemberian macam bokashi dan varietas.

\begin{tabular}{lcccc}
\hline \multirow{2}{*}{ Perlakuan } & \multicolumn{4}{c}{ Rata-rata tinggi tanaman $(\mathrm{cm})$ pada tanaman umur } \\
\cline { 2 - 5 } & $14 \mathrm{hst}$ & $28 \mathrm{hst}$ & $42 \mathrm{hst}$ & $56 \mathrm{hst}$ \\
\hline Tanpa bokashi, BISI 18 & $25,73 \mathrm{~cd}$ & $76,33 \mathrm{de}$ & $175,00 \mathrm{~d}$ & $224,73 \mathrm{fg}$ \\
Tanpa bokashi, NK7328 SUMO & $26,33 \mathrm{bc}$ & $77,80 \mathrm{~cd}$ & $176,13 \mathrm{~cd}$ & $225,73 \mathrm{def}$ \\
Tanpa bokashi, BISI 2 & $25,27 \mathrm{~cd}$ & $76,27 \mathrm{e}$ & $174,67 \mathrm{e}$ & $224,53 \mathrm{~g}$ \\
Bokashi kandang sapi, BISI 18 & $26,33 \mathrm{bc}$ & $77,27 \mathrm{~cd}$ & $176,47 \mathrm{~cd}$ & $226,07 \mathrm{de}$ \\
Bokashi kandang sapi, NK7328 SUMO & $27,93 \mathrm{~b}$ & $78,27 \mathrm{c}$ & $177,67 \mathrm{c}$ & $227,20 \mathrm{c}$ \\
Bokashi kandang sapi, BISI 2 & $26,73 \mathrm{bc}$ & $75,13 \mathrm{f}$ & $175,53 \mathrm{~cd}$ & $225,20 \mathrm{efg}$ \\
Bokashi kandang ayam, BISI 18 & $27,80 \mathrm{~b}$ & $80,53 \mathrm{~b}$ & $182,67 \mathrm{ab}$ & $228,27 \mathrm{~b}$ \\
Bokashi kandang ayam, NK7328 SUMO & $32,13 \mathrm{a}$ & $85,87 \mathrm{a}$ & $184,93 \mathrm{a}$ & $230,47 \mathrm{a}$ \\
Bokashi kandang ayam, BISI 2 & $26,87 \mathrm{bc}$ & $77,73 \mathrm{~cd}$ & $177,13 \mathrm{~cd}$ & $226,60 \mathrm{~cd}$ \\
\hline \multicolumn{1}{c}{ BNT 5\% } & 1,76 & 2,83 & 2,59 & 1,04 \\
\hline
\end{tabular}

Keterangan : Angka-angka yang diikuti oleh huruf yang sama dalam kolom yang sama tidak berbeda nyata dengan uji BNT 5\%.

Pada Tabel 1. dapat dilihat bahwa pengamatan parameter tinggi tanaman jagung menunjukkan interaksi antara perlakuan macam bokashi dan varietas.
Nilai terbaik ditunjukkan oleh perlakuan bokashi kandang ayam dan varietas jagung NK7328 SUMO. 
Agroradix Vol. 2 No.2 Juni (2019)

ISSN : 2621-0665

Jumlah Daun

Hasil analisa sidik ragam menunjukkan bahwa tidak terdapat interaksi antara perlakuan bokashi dan perlakuan varietas terhadap jumlah daun pada pengamatan umur $14 \mathrm{hst}, 28 \mathrm{hst}, 42$ hst, dan 56 hst. Rata-rata jumlah daun dapat dilihat pada Tabel 2 .

Tabel 2. Rata-rata jumlah daun tanaman jagung terhadap pemberian macam bokashi dan varietas.

\begin{tabular}{|c|c|c|c|c|}
\hline \multirow{2}{*}{ Perlakuan } & \multicolumn{4}{|c|}{ Rata-rata jumlah daun (helai) pada pengamatan umur } \\
\hline & $14 \mathrm{hst}$ & $28 \mathrm{hst}$ & $42 \mathrm{hst}$ & 56 hst \\
\hline Tanpa bokashi & $4,53 \mathrm{~b}$ & $8,40 \mathrm{~b}$ & $10,33 \mathrm{~b}$ & $15,07 \mathrm{c}$ \\
\hline Bokashi kandang sapi & $4,64 \mathrm{~b}$ & $8,47 \mathrm{ab}$ & $10,56 b$ & $15,38 \mathrm{~b}$ \\
\hline Bokashi kandang ayam & $4,80 \mathrm{a}$ & $8,62 \mathrm{a}$ & 10,67 a & 15,82 a \\
\hline BNT $5 \%$ & 0,21 & 0,13 & 0,36 & 0,23 \\
\hline BISI 18 & $4,67 \mathrm{~b}$ & $8,49 \mathrm{~b}$ & $10,67 \mathrm{~b}$ & $15,42 \mathrm{~b}$ \\
\hline NK7328 SUMO & $4,82 \mathrm{a}$ & $8,60 \mathrm{a}$ & 10,78 a & $15,60 \mathrm{a}$ \\
\hline BISI 2 & $4,49 \mathrm{~b}$ & $8,40 \mathrm{~b}$ & $10,11 \mathrm{c}$ & $15,24 c$ \\
\hline BNT 5\% & 0,21 & 0,13 & 0,36 & 0,23 \\
\hline
\end{tabular}

Keterangan : Angka-angka yang diikuti oleh huruf yang sama dalam kolom yang sama tidak berbeda nyata dengan uji BNT 5\%.

Pada Tabel 2. dapat dilihat bahwa terdapat perbedaan nyata dan sangat nyata pada perlakuan bokashi dan varietas pada pengamatan jumlah daun tanaman jagung, dengan hasil terbaik pada perlakuan bokashi kandang ayam dan perlakuan varietas NK7328 SUMO.

\section{Panjang Tongkol Kupasan Lepas Panen dan Diameter Tongkol Kupasan Lepas Panen}

Hasil analisa sidik ragam menunjukkan bahwa terdapat hasil beda sangat nyata pada perlakuan varietas terhadap panjang tongkol kupasan lepas panen dan diameter tongkol kupasan lepas panen per tanaman sampel. Rata-rata panjang tongkol kupasan lepas panen dan diameter tongkol kupasan lepas panen per tanaman sampel dapat dilihat pada Tabel 3.

Tabel 3. Rata-rata panjang tongkol kupasan lepas panen dan diameter tongkol kupasan lepas panen per tanaman sampel.

\begin{tabular}{lcc}
\hline Perlakuan & $\begin{array}{c}\text { Rata-rata panjang tongkol } \\
\text { kupasan lepas panen }(\mathrm{cm}) \\
\text { per tanaman sampel }\end{array}$ & $\begin{array}{c}\text { Rata-rata diameter tongkol } \\
\text { kupasan lepas panen }(\mathrm{cm}) \\
\text { per tanaman sampel }\end{array}$ \\
\hline BISI 18 & $17,92 \mathrm{~b}$ & $4,52 \mathrm{~b}$ \\
NK7328 SUMO & $18,87 \mathrm{a}$ & $4,74 \mathrm{a}$ \\
BISI 2 & $18,01 \mathrm{~b}$ & $4,13 \mathrm{c}$ \\
\hline \multicolumn{1}{c}{ BNT 5\% } & 0,51 & 0,09 \\
\hline
\end{tabular}

Keterangan : Angka-angka yang diikuti oleh huruf yang sama dalam kolom yang sama tidak berbeda nyata dengan uji BNT 5\%. 
Pada Tabel 3. dapat dilihat bahwa terdapat hasil beda sangat nyata pada perlakuan varietas terhadap panjang tongkol kupasan lepas panen per tanaman sampel dengan hasil rata-rata $18,87 \mathrm{~cm}$ dan diameter tongkol kupasan lepas panen per tanaman sampel dengan hasil rata-rata 4,74 cm. Dengan hasil terbaik pada perlakuan varietas NK7328 SUMO pada setiap masing-masing parameter pengamatan.
Berat Tongkol Kupasan Lepas Panen per
Tanaman Sampel dan Berat Tongkol
Kupasan Lepas Panen per Hektar
Hasil analisa sidik ragam menunjukkan bahwa terdapat hasil beda sangat nyata pada perlakuan varietas terhadap berat tongkol kupasan lepas panen per tanaman sampel dan berat tongkol kupasan lepas panen per hektar. Rata-rata berat tongkol kupasan lepas panen per tanaman sampel dan berat tongkol kupasan lepas panen per hektar dapat dilihat pada Tabel 4 .

Tabel 4. Rata-rata berat tongkol kupasan lepas panen per tanaman sampel dan berat tongkol kupasan lepas panen per hektar.

\begin{tabular}{lcc}
\hline Perlakuan & $\begin{array}{c}\text { Rata-rata berat tongkol } \\
\text { kupasan lepas panen } \\
\text { per tanaman sampel }(\mathrm{g})\end{array}$ & $\begin{array}{c}\text { Rata-rata berat tongkol kupasan } \\
\text { lepas panen (ton) } \\
\text { per hektar }\end{array}$ \\
\hline BISI 18 & $216,04 \mathrm{~b}$ & $1,50 \mathrm{~b}$ \\
NK7328 SUMO & $244,40 \mathrm{a}$ & $1,69 \mathrm{a}$ \\
BISI 2 & $171,11 \mathrm{c}$ & $1,19 \mathrm{c}$ \\
\hline \multicolumn{1}{c}{ BNT 5\% } & 13,19 & 0,09 \\
\hline
\end{tabular}

Keterangan : Angka-angka yang diikuti oleh huruf yang sama dalam kolom yang sama tidak berbeda nyata dengan uji BNT $5 \%$.

Pada Tabel 4. dapat dilihat bahwa terdapat hasil beda sangat nyata pada perlakuan varietas terhadap berat tongkol kupasan lepas panen per tanaman sampel, dengan hasil rata-rata $244,40 \mathrm{~g}$. dan berat tongkol kupasan lepas panen per hektar, dengan hasil rata-rata 1,69 t/ha. Dengan hasil terbaik pada perlakuan varietas NK7328 SUMO pada setiap masing-masing parameter pengamatan.

\section{Berat 1000 Biji}

Hasil analisa sidik ragam menunjukkan bahwa terdapat hasil beda nyata pada perlakuan bokashi terhadap berat 1000 biji per petak perlakuan, sedangkan terdapat hasil beda sangat nyata pada perlakuan varietas terhadap berat 1000 biji per petak perlakuan. Ratarata hasil berat 1000 biji per petak perlakuan dapat dilihat pada Tabel 5 . 
Agroradix Vol. 2 No.2 Juni (2019)

ISSN : 2621-0665

Tabel 5. Rata-rata berat 1000 biji per petak perlakuan.

\begin{tabular}{|c|c|}
\hline Perlakuan & Rata-rata berat 1000 biji per petak perlakuan (g) \\
\hline Tanpa bokashi & $357,78 \mathrm{~b}$ \\
\hline Bokashi kandang sapi & $366,89 a$ \\
\hline Bokashi kandang ayam & $372,11 \mathrm{a}$ \\
\hline BNT 5\% & 8,76 \\
\hline BISI 18 & $341,78 \mathrm{c}$ \\
\hline NK7328 SUMO & 401,44 a \\
\hline BISI 2 & $353,56 \mathrm{~b}$ \\
\hline
\end{tabular}

Keterangan : Angka-angka yang diikuti oleh huruf yang sama dalam kolom yang sama tidak berbeda nyata dengan uji BNT 5\%.

Pada Tabel 5. dapat dilihat bahwa pada parameter pengamatan berat 1000 biji terdapat perbedaan nyata pada perlakuan bokashi dengan hasil terbaik pada perlakuan bokashi kandang ayam dengan hasil rata-rata $372,11 \mathrm{~g}$. Selain itu pada pengamatan berat 1000 biji juga terdapat perbedaan sangat nyata pada perlakuan varietas dengan hasil terbaik pada perlakuan varietas NK7328 SUMO dengan hasil rata-rata 401,44 g.

\section{PEMBAHASAN}

Berdasarkan hasil analisa sidik ragam dari parameter pengamatan fase vegetatif meliputi tinggi tanaman dan jumlah daun. Perlakuan bokashi dan varietas menunjukkan interaksi terhadap tinggi tanaman jagung (Tabel 1). Perlakuan bokashi kandang ayam dan varietas NK7328 SUMO menghasilkan nilai yang lebih baik dibanding perlakuan lainnya. Sedangkan terdapat hasil beda nyata dan sangat nyata pada perlakuan bokashi terhadap jumlah daun tanaman jagung (Tabel 2).

Menurut pendapat Djunaedy (2009), penambahan bokashi secara tidak langsung dapat meningkatkan aktivitas fotosintesis tanaman. Bokashi mengandung mikroorganisme EM4 yang memiliki peran penting dalam meningkatkan bakteri fotosintetik dan bakteri pengikat nitrogen di dalam tanah. Diduga pengaplikasian bokashi kandang ayam mengandung sejumlah unsur hara yang kompleks dan bahan organik yang dapat memperbaiki sifat fisik, kimia, dan biologi tanah. Perbaikan sifat biologi tanah karena bahan organik sebagai sumber energi dari sebagian besar organisme tanah (Sahetapy, 2017).

Nitrogen merupakan unsur yang sangat penting dalam pembentukan klorofil yang berperan penting dalam fotosintesis. Unsur hara Nitrogen merupakan unsur hara yang sangat dibutuhkan tanaman jagung untuk proses pertumbuhan. Apabila unsur hara tersebut tersedia dalam jumlah sedikit, maka akan mempengaruhi pertumbuhan tanaman jagung. Menurut Subhan (2008), penambahan unsur hara Nitrogen dapat menurunkan $\mathrm{C} / \mathrm{N}$ bahan organik. Sehingga bahan organik cepat terurai, semakin cepat bahan organik terurai maka semakin cepat unsur hara esensial yang akan diserap oleh tanaman. Penambahan bokashi ke dalam tanah dapat meningkatkan kandungan bahan organik dan unsur hara Nitrogen dalam tanah. 
Menurut Latarang (2006), menyatakan bahwa pembentukan jumlah daun sangat ditentukan oleh jumlah dan ukuran sel dari tanaman. Selain itu juga dipengaruhi oleh unsur hara yang diserap oleh akar tanaman untuk dijadikan sebagai bahan makanan. Adanya unsur hara Nitrogen yang berfungsi sebagai penyusun enzim dan molekul klorofil. Radium berfungsi sebagai aktivator berbagai enzim sintesa protein maupun metabolisme karbohidrat. Sedangkan fosfor berperan aktif dalam mentrasfer energi di dalam sel tanaman dan magnesium sebagai penyusun klorofil dan membantu translokasi fosfor dalam tanaman.

Perlakuan varietas menunjukkan interaksi terhadap tinggi tanaman tanaman jagung (Tabel 1) dan terdapat perbedaan nyata dan sangat nyata terhadap jumlah daun tanaman jagung (Tabel 2). Dimana varietas NK7328 SUMO memberikan respon yang lebih baik, dalam pertumbuhan tinggi tanaman dan jumlah daun tanaman jagung dibanding dengan varietas BISI 18 dan BISI 2. Hal ini diduga morfologi atau gen-gen penyusun varietas NK7328 SUMO mengatur karakter dari tinggi tanaman dan jumlah daun sesuai dengan keadaan lingkungan sekitarnya. Sehingga dapat mempengaruhi pertumbuhan dari tanaman jagung tersebut.

Menurut Kuruseng (2008), gen-gen yang beragam dari masing-masing varietas mempunyai karakter-karakter yang beragam pula. Lingkungan memberikan peran dalam rangka untuk menampakan karakter yang sebenarnya terkandung dalam gen varietas tersebut. Selanjutnya Maruapey (2012), menjelaskan bahwa setiap tanaman memiliki susunan genetik yang berbeda-beda, sehingga karakter yang dihasilkan oleh suatu tanaman berbeda pula dengan karakter yang dimiliki oleh tanaman lainnya.

Sedangkan parameter pengamatan pada fase generatif meliputi panjang tongkol kupasan lepas panen, diameter tongkol kupasan lepas panen, berat tongkol kupasan lepas panen per tanaman sampel, berat tongkol kupasan lepas panen per hektar dan berat 1000 biji. Diketahui bahwa dari hasil penelitian tersebut, perlakuan bokashi belum bisa maksimal memberikan respon yang baik terhadap beberapa parameter pengamatan tersebut. Hal ini diduga karena bokashi merupakan pupuk organik yang lebih dominan berperan sebagai perbaikan sifat fisik tanah sehingga tidak memengaruhi pola aktivitas tanaman secara signifikan.

Perlakuan dari berbagai macam varietas menghasilkan umur berbunga (pollen) tanaman jagung hibrida yang tidak seragam keluarnya. Hal ini diduga menyebabkan panjang tongkol jagung hibrida yang bervariasi dan menghasilkan panjang tongkol jagung hibrida yang berbeda-beda, ada yang lebih panjang dan ada juga yang lebih pendek. Selain itu yang menyebabkan umur keluarnya rambut tongkol jagung hibrida tidak seragam keluarnya. Mungkin disebabkan adanya faktor eksternal dan internal, seperti faktor lingkungan misalnya sinar matahari, angin dan hujan dan faktor genetik dari masingmasing varietas itu sendiri.

Menurut Robaniah (2019), cekaman fisiologis pada awal fase generatif akan menunda proses pembentukan bunga betina (rambut tongkol). Hal ini disebabkan pada fase generatif merupakan fase terlemah tanaman jagung hibrida terhadap cekaman. Pada fase ini tanaman jagung hibrida sedang mengumpulkan energi yang 
cukup untuk membentuk organ generatif dan penyimpanan makanan. Sehingga membutuhkan unsur hara dan ketersediaan air yang cukup.

Perlakuan varietas berpengaruh sangat nyata terhadap panjang tongkol kupasan lepas panen per tanaman sampel (Tabel 3), hal ini diduga dari setiap varietas tanaman jagung yang diamati yaitu varietas BISI 18, varietas NK7328 SUMO dan varietas BISI 2 memiliki perbedaan sifat atau karakter masing-masing sesuai dengan sifat genetiknya. Sehingga panjang tongkol tanaman jagung yang dihasilkan berbeda-beda ukuran panjangnya.

Perbedaan diameter tongkol kupasan lepas panen per tanaman sampel (Tabel 3) diduga faktor genetik dari masingmasing varietas yang diamati yaitu varietas jagung BISI 18, NK7328 SUMO dan BISI 2. Genotip yang berbeda-beda dari varietas tersebut akan memberikan respon yang berbeda-beda pula, jika ditanam pada lingkungan yang sama dan demikian sebaliknya (Kuruseng, 2008).

Menurut Sidar (2010), unsur $P$ sangat dibutuhkan tanaman jagung pada fase generative dalam pembentukan tongkol. Kekurangan unsur hara tersebut maka perkembangan tongkol dan stigma tidak lengkap. Akibatnya terjadi penyerbukan tanaman jagung yang tidak sempurna. Sehingga menghasilkan biji yang tidak merata dan tidak bernas yang akan menyebabkan produksi tanaman jagung menurun. Unsur hara $P$ berfungsi dalam memperbaiki kualitas bobot tongkol dan unsur hara Kalium dalam mempercepat reaksi laju fotosintesis dan translokasi dalam meningkatkan bobot tongkol.

Doni (2008), menyatakan bahwa apabila pertumbuhan tanaman terhambat, maka kelancaran translokasi unsur hara dan fotosintat kebagian tongkol juga akan terhambat. Akibatnya berat tongkol tanaman jagung akan ringan sehingga produksinya akan sedikit pula.

Perlakuan varietas yang berbeda juga memberikan pengaruh sangat nyata terhadap berat tongkol kupasan lepas panen per tanaman sampel (Tabel 4). Hal ini diduga adanya perbedaan genetik dari masing-masing varietas yang diamati. Menurut Kuruseng (2008), varietas merupakan golongan tanaman yang memiliki ciri khas seragam dan stabil serta memiliki perbedaan yang mutlak dari varietas tanaman lainnya. Demikian halnya dengan ketiga macam varietas jagung hibrida yang diamati. Meskipun ketiganya tergolong varietas jagung hibrida yang unggul, tetapi adanya perbedaan sifat dan karakteristik dari varietas tersebut. Maka sifat-sifat yang dimunculkan juga berbeda meskipun ketiganya ditanam pada suatu kondisi lingkungan yang relatif sama.

Ukuran tongkol yang dihasilkan oleh tanaman jagung, sangat berhubungan dengan jumlah biji yang terdapat pada tongkolnya (Faisal, 2011). Semakin panjang dan besar diameter tongkol jagung kupasan lepas panen, maka akan semakin banyak jumlah biji yang dihasilkan dari masing-masing tongkol jagung. Tingginya produksi tanaman jagung dipengaruhi oleh pertumbuhannya. Pertumbuhan tanaman jagung yang baik akan mendukung produktivitas yang baik pula. Karena proses yang terjadi pada tanaman jagung akan berlangsung dengan baik. Maruapey (2010), berpendapat bahwa produksi suatu tanaman merupakan resultante dari proses fotosintesa, penurunan asimilat akibat respirasi dan translokasi bahan kering ke dalam hasil tanaman. 
Perlakuan varietas NK7328 SUMO menunjukkan pertumbuhan yang sangat baik terhadap parameter pengamatan tinggi tanaman, jumlah daun, panjang tongkol kupasan lepas panen, diameter tongkol kupasan lepas panen dan berat tongkol kupasan lepas panen per tanaman sampel. Sehingga akan mendukung untuk menghasilkan berat tongkol kupasan lepas panen per hektar yang tinggi dengan hasil rata-rata 1,69 t/ha (Tabel 4).

Perlakuan bokashi kandang ayam menunjukkan hasil terbaik terhadap berat 1000 biji per petak perlakuan dengan hasil rata-rata 372,11 g (Tabel 5). Hal ini diduga peranan unsur Kalium dalam bokashi kandang ayam, yang membantu produksi tanaman khususnya dalam pertumbuhan biji. Menurut pendapat Maruapey (2012), unsur kalium berperan penting dalam pembentukan dan translokasi karbohidrat.

$\mathrm{Hal}$ ini diduga dengan pengaplikasian bokashi kandang ayam telah memberikan sokongan yang cukup untuk lancarnya translokasi dan pembentukan karbohidrat yang dibutuhkan untuk pertumbuhan organ generatif, yaitu pada pertumbuhan biji sehingga akan meningkatkan produksi yang dihasilkan. Selanjutnya menurut Maruapey (2010), mengemukakan bahwa unsur $\mathrm{K}$ berperan penting dalam pembentukan karbohidrat dan aktivitas enzim. Sementara menurut Ibrahim (2013), berpendapat bahwa unsur $\mathrm{K}$ berperan penting dalam meningkatkan ukuran dan bobot biji.

Perlakuan varietas NK7328 SUMO menunjukkan hasil yang terbaik terhadap berat 1000 biji per petak perlakuan dengan hasil rata-rata 401,44 g (Tabel 5) dibanding dengan perlakuan varietas lainnya. Hal ini diduga genotip dari masing-masing varietas, memberikan respon yang berbeda jika ditanam pada lahan atau lingkungan yang sama.

\section{KESIMPULAN DAN SARAN}

\section{Kesimpulan}

Berdasarkan hasil penelitian yang telah dilakukan pada perlakuan macam bokashi dan varietas terhadap pertumbuhan dan produksi tanaman jagung (Zea mays L.) dapat disimpulkan bahwa :

Terdapat interaksi antara perlakuan macam bokashi dan varietas terhadap tinggi tanaman jagung. Perlakuan bokashi kandang ayam dan varietas jagung NK7328 SUMO menghasilkan nilai yang lebih baik dibanding perlakuan lainnya.

Perlakuan varietas NK7328 SUMO berpengaruh baik pada parameter pengamatan jumlah daun, panjang tongkol kupasan lepas panen, diameter tongkol kupasan lepas panen, berat tongkol kupasan lepas panen dan berat 1000 biji.

Perlakuan varietas NK7328 SUMO menghasilkan produksi berat tongkol per hektar yang lebih tinggi dibanding perlakuan lainnya, dengan hasil rata-rata $1,69 \mathrm{t} / \mathrm{ha}$.

\section{Saran}

Perlu dilakukan penelitian lebih lanjut pada perlakuan varietas NK7328 SUMO terhadap pemberian pupuk organik, dikarenakan varietas tersebut memiliki keunggulan yaitu pertumbuhan tanaman yang baik dan produktivitas yang tinggi dibanding dengan varietas tanaman jagung lainnya. 


\section{DAFTAR PUSTAKA}

Djunaedy A. 2009. Pengaruh jenis dan dosis pupuk bokashi terhadap pertumbuhan dan hasil kacang panjang (Vigna sinensis L.). Agrovigor. 2 (1): 42-46.

Doni. 2008. Pengaruh Dosis dan Waktu Pemberian Pupuk $\mathrm{N}$ dan K Terhadap Pertumbuhan dan Produksi Jagung Manis Seleksi Dermaga 2 (SD2). J.II. Pert Indonesia 2 (1): 1-6.

Faisal, Bahtiar, AC. Turang. 2011. Kelayakan Usahatani Jagung Komposit Varietas BISMA di Tomohon Sulawesi Utara. Serealia: 635-461

Ibrahim, Roli. dkk. 2013. Respon Beberapa Varietas Tanaman Jagung (Zea mays L.) Hibrida pada Berbagai Dosis Pupuk Kalium terhadap Pertumbuhan dan Hasil Beberapa Varietas Jagung (Zea mays L.) Hibrida.

Kuruseng, H. dan M. A. Kuruseng. 2008. Pertumbuhan dan Produksi Berbagai Varietas Tanaman Jagung pada Dua Dosis Pupuk Urea. Jurnal Agrisistem 4 (1): 26-36.

Kusuma ME. 2013. Pengaruh pemberian bokashi terhadap pertumbuhan vegetatif dan produksi rumput gajah (Pennisetum purpureum). IImu Hewani Tropika 2 (2): 40-45.

Latarang, B. dan A. Syakur. 2006. Pertumbuhan dan Hasil Bawang Merah (Allium ascalonicum L.) pada Berbagai Dosis Pupuk Kandang. J. Agroland 13 (3) : 265 - 269.

Maruapey A, Faesal. 2010. Pengaruh pemberian pupuk $\mathrm{KCl}$ terhadap pertumbuhan dan hasil jagung pulut
(Zea mays ceratina. L). Serealia Nasional: 315-326.

Maruapey, A. 2012. Pengaruh Dosis Pemupukan Kalium terhadap Pertumbuhan dan Produksi Berbagai Asal Jagung Pulut (Zea mays certaina L.). Jurnal Agroforestri 7 (1): 33-41.

Ratna W.A. dan Robet A. 2009. Kandungan Gizi dan Komposisi Asam Amino Beberapa Varietas Jagung. Jurnal Penelitian Pertanian Terapan. Politeknik Negeri Lampung. Unit Penelitian kepada Masyarakat 9 (2): 61-66.

Robaniah. 2019. Pengaruh Pupuk Bokashi Dan Varietas Terhadap Pertumbuhan Dan Hasil Tanaman Jagung Manis (Zea mays saccharata Sturt). Jurnal Agrifor 18 (1).

Sahetapy, M.M. dkk. 2017. Analisis Pengaruh Beberapa Dosis Pupuk Bokashi Kotoran Ayam Terhadap Pertumbuhan Dan Produksi Tiga Varietas Tomat (Lycopersicum Esculentum Miil.) Di Desa Airmadidi. Jurnal AgriSosioEkonomi 13 (2 A): 71 - 82.

Sidar. 2010. Pengaruh Kompos Sampah Kota dan Pupuk Kandang Ayam terhadap Beberapa Sifat Kimia Tanah dan Hasil Tanaman Jagung Manis (Zea mays Saccharata Sturt) Pada Fluventic Eutrupdepts asal Jatinangor kabupaten Sumedang.

Subhan, F., Hamzah dan A., Wahab. 2008. Aplikasi Bokashi Kotoran Ayam Pada Tanaman Melon. Jurnal Agrisistem 4 (1). 
Agroradix Vol. 2 No.2 Juni (2019)

ISSN : 2621-0665

Suryana, A. 2010. Panduan Pengelolaan Tanaman Terpadu (PTT) Jagung. Balai Penelitian Tanaman Pangan, Pusat Penelitian dan Pengembangan Pertanian, Kementrian Pertanian. Bogor.

Sutedjo, M. 2010. Pupuk dan Pemupukan. PT. Rineka Cipta. Jakarta. 